\title{
Radiological Hazard Resulting from using Ceramic Tile in Egypt
}

\author{
M. A. M. Uosif ${ }^{1 *}$, M Omer ${ }^{2}$, Nagwa A. Ali ${ }^{2}$, A. H. El-Kamel ${ }^{2}$ and M. A. Hefni ${ }^{2}$ \\ ${ }^{1}$ Physics Department, Faculty of Sciences, Al-Azhar University (Assiut branch), \\ Egypt \\ ${ }^{2}$ Physics Department, Faculty of Sciences, Assiut University, Egypt \\ *Corresponding author:dr_mohamed_amin@lycos.com
}

\begin{abstract}
In this study the radiological hazard Resulting from the using of ceramic tile locally produced and commonly used as building materials in Egypt have been done by determining the contents of natural radionuclides $\left({ }^{226} \mathrm{Ra},{ }^{232} \mathrm{Th}\right.$ and $\left.{ }^{40} \mathrm{~K}\right)$ by using gamma spectrometry (HPGe) detector. The measured average activity concentrations of ${ }^{226} \mathrm{Ra}$, ${ }^{232}$ Thand ${ }^{40} \mathrm{~K}$ were $47.4 \pm 3.3,42.84 \pm 2.8$ and $313.6 \pm 34.3 \mathrm{Bqkg}^{-1}$ respectively. The obtained concentrations were compared with the reported data of other countries. The R $a_{e q}$ values of all samples were lower than the limit of $370 \mathrm{~Bq} . \mathrm{kg}^{-1}$, equivalent to a gamma dose of 1.5 $m S v \cdot a^{-1}$ recommended by OECD. With average total annual dose being only $0.07 \mathrm{mSv} \mathrm{y}^{-1}$, this value is about $7 \%$ of the $1.0 \mathrm{mSv} y^{-1}$ recommended by the International Commission on Radiological Protection (ICRP-60, 1990) as the maximum annual dose to members of the public.
\end{abstract}

Key words: Radiological pollution, ceramic tile materials, total annual dose (HpGe) detector

\section{Introduction}

The ceramic tiles are commonly used in most modern houses for the interior decoration of walls and floors in bathrooms, kitchens, medical centers, labs, schools, public conveniences, and shopping malls. The production of ceramic tiles (floor and wall) is one of the very fast growing industries in the last three decades in Egypt. Ceramics industry is an attractive method in management of hazardous solid wastes for environmental and public health protection. It can be used to treat a wide variety of wastes and contaminants, including organics and inorganics (heavy metals, radioactive wastes and asbestos).

Ceramic is composed of two main components: the tile body and the tile glaze. The tile body is derived from clay minerals mined from the Earth`s crust and is usually produced with variable purity. The second component of the tile is the shiny tile glaze, which typically consists of one or more layers with a total thickness between 75 and 500 microns, covering the surface side of the ceramic tiles. This substance is usually a glass material glaze composed of inorganic raw materials, with $\mathrm{SiO} 2$ as the main component [1]. Kaolins are the second largest component of the tile glaze and are used to keep the enamel particles in suspension. Feldspar provides a source of sodium and potassium and acts as a flux to lower the glaze melting. Ceramic is a refractory, inorganic and nonmetallic material. Zircon sand is often used in the fine ceramics industry, where it acts as a pacifier in glazes and enamels, and it is also used as an additive in the glazing of ceramic tiles.

Ceramic can be divided into two classes: traditional and advanced

i. Traditional ceramic includes clay products, silicate glass and cement.

ii. Advanced ceramic (porcelain tiles)consists of carbides ( $\mathrm{SiC}$ ), pure oxides $\left(\mathrm{Al}_{2} \mathrm{O}_{3}\right)$, nitrides $\left(\mathrm{Si}_{3} \mathrm{~N}_{4}\right)$, non-silicate glass and many others [2] 
They can show natural activity concentration significantly higher than the average values of Earth's crust. [3]. The concentrations of natural radionuclides uranium $\left({ }^{238} \mathrm{U}\right)$ and thorium $\left({ }^{232} \mathrm{Th}\right)$ series, and ${ }^{40} \mathrm{~K}$, which present in ceramic materials, vary depending upon the local geological conditions. These radionuclides cause external and internal radiation exposure to occupants. The external exposure is caused by direct gamma radiation.

The internal radiation exposure, affecting the respiratory tract, is due to radon and its decay products which emanate from building materials [4]. Because most of the people spend $\sim 80 \%$ of their time indoors, so we pay attention to the low-level exposure from naturally occurring radionuclides. It is well known that, the long exposures to low levels of ionizing radiation can seriously increase health risks to humans. It can be setting controls on the radioactivity of roofing tiles is to limit the radiation exposure due to materials with enhanced or elevated levels of natural radionuclides. The doses to the members of the public should be kept as low as reasonably achievable. However, since small exposures from roofing tiles are in all places, controls should be based on exposure levels which are above typical levels of exposures and their normal variations [4].

In Egypt the information about the radioactivity of ceramic tile materials is still limited consequently; this study was undertaken with the purpose of determining natural radioactivity in ceramic tile materials and associated radiological hazards.

\section{Materials and Methods}

\subsection{Sample Description and Preparation}

To assess the natural radioactivity in the ceramic tile, a total of 97samples of commercial ceramic tiles of ten different Egyptian brands locally manufactured were collected. The names of different samples of ceramic roofing tiles are (RoR, PrR, LR, GIR, GR, FrR, KR, ArR, AlR, FR), while the names of different samples ceramic wall tiles are $(\mathrm{RoH}, \mathrm{PrH}, \mathrm{LH}, \mathrm{GlH}, \mathrm{GH}, \mathrm{FrH}, \mathrm{KH}, \mathrm{ArH}, \mathrm{AlH}, \mathrm{FH})$. Finally the advanced ceramic tiles (porcelain) have names (PG, PK, PPr).The number of samples for the three different types of ceramic tiles was 42 ceramic walls tile, 44flooring tile and 11 advanced ceramic (porcelain) tiles. These particular types were considered important because they are usually used in the construction of houses in Egypt. The samples were obtained from suppliers or gathered directly in demolished houses or buildings under construction.

All samples were crushed to a fine powder and sieved through a 200- mm mesh, which is the optimum size enriched in heavy minerals. Each sample was dried in an oven at $110 \sim{ }^{\circ} \mathrm{C}$ to ensure that moisture was completely removed. Weighed samples were placed in a polyethylene cylindrical beaker, of about $200-\mathrm{cm}^{3}$ volumeeach.These beakers have been sealed to prevent the escape of gaseous $\mathrm{Rn}^{222}$ from the samples and kept for about 30 days to ensure secular equilibrium between $\mathrm{Ra}^{226}$ and $\mathrm{Th}^{232}$ and their decay products, where the rate of decay of the progeny becomes equal to that of the parent (radium and thorium) within the volume and the progeny will also remain in the sample [5].

\subsection{Radiometric Analysis}

For gamma spectrometry analysis, all samples were analyzed after collection by low-background gamma spectroscopy using HPGe detector (Canberra, GR4020 model) with relative efficiency $40 \%$ for $3 "$ x 3 " $\mathrm{NaI}(\mathrm{Tl})$ crystal, and energy resolution of 2 $\mathrm{keV}$ at the $1332 \mathrm{keV}$ gamma of ${ }^{60} \mathrm{Co}$.The detector was shielded in a $6.22 \mathrm{~cm}$ thick lead well internally lined with $0.6 \mathrm{~mm}$ Carbon composite. The detector output was connected to spectroscopy amplifier (Canberra, Model, 2002CSL).The energy calibration for the system is carried out using point sources of $\left(\mathrm{Ba}^{133}, \mathrm{Co}^{60}, \mathrm{Cs}^{13}, \mathrm{Mn}^{54}, \mathrm{Na}^{22}\right.$, and $\left.\mathrm{Zn}^{65}\right)$. This spectrometer was equipped with LabSOCSs (Laboratory Source less Calibration Software). Basic calibration measurements had been done at the factory; results were used 
to establish the detector's characterization file. The LabSOCSs calibration tool takes into account the sample to detector geometry, sample density and composition, as well as measurement container properties. To validate and check the efficiency data supplied by LabSOCSs, measurements were performed in our laboratory by using a set of calibrated point sources, $\left(\mathrm{Ba}^{133}, \mathrm{Co}^{60}\right.$ and $\left.\mathrm{Cs}^{137}\right)$ positioned at a distances between 0 and $15 \mathrm{~cm}$ from the detector end-cap. The calculated results show good agreement between mathematical and empirical peak efficiencies with differences less than $10 \%$.

For spectral analysis, the software Genie 2000 (Canberras, USA) has been used. The counting time of the measurements was $28800 \mathrm{~s}$ for activity or background. To determine the background radiation level, an empty cylindrical beaker was counted at the same time as the samples under identical geometry. The background spectra were used to correct the net peak area of gamma rays of measured isotopes. The ${ }^{226} \mathrm{Ra}$ radionuclide have been estimated from the 351.9keV (36.7\%) gamma peak of ${ }^{214} \mathrm{~Pb}$ and $609.3 \mathrm{keV}(46.1 \%)$, $1120.3 \mathrm{keV}(15 \%)$ and $1764 \mathrm{keV}(15.9 \%)$ gamma peaks of ${ }^{214} \mathrm{Bi}$. On the other hand the ${ }^{232} \mathrm{Th}$ radionuclide was estimated from the $911.2 \mathrm{keV}(29 \%)$ gamma peak of ${ }^{228} \mathrm{Ac}$, the238.6keV (43.6\%) gamma peak of ${ }^{212} \mathrm{~Pb}$ and $2614 \mathrm{keV}$ gamma ray from ${ }^{208} \mathrm{Tl}$. While the ${ }^{40} \mathrm{~K}$ radionuclide was estimated using the $1461 \mathrm{keV}(10.7 \%)$ gamma peak from ${ }^{40} \mathrm{~K}$ itself.

\subsection{Activity Concentration:}

The calculations of the activity concentration $\left(A_{c}\right)$ values for radionuclides from the ${ }^{235} \mathrm{U},{ }^{238} \mathrm{U}$ and ${ }^{232} \mathrm{Th}$ series and ${ }^{40} \mathrm{~K}$ present in roofing tile samples can be determined as [6]:

$$
A c=\frac{C_{n e t}}{\gamma \times \varepsilon \times m \times t}
$$

Where $\mathrm{C}_{\text {net }}$ represent peak net counts, $\gamma$ represent the emission probability of specific energy peak, $\varepsilon$ is the absolute efficiency of the full energy peak of the detector, $m$ is the mass sample in $\mathrm{Kg}$ and $t$ is the time of count.

\subsection{The Radium Equivalent Activity:}

The distribution of ${ }^{226} \mathrm{Ra},{ }^{232} \mathrm{Th}$ and ${ }^{40} \mathrm{~K}$ in ceramic is not uniform. Uniformity with respect to exposure to radiation has been defined in terms of radium equivalent activity $\left(\mathrm{Ra}_{\mathrm{eq}}\right)$ in $\mathrm{Bq} \mathrm{kg}{ }^{-1}$ to compare the specific activity of materials containing different amounts of ${ }^{226} \mathrm{Ra},{ }^{232} \mathrm{Th}$ and ${ }^{40} \mathrm{~K}$.It is calculated through the following relation [7]:

$$
R a_{e q}=C_{R a}+1.43 C_{T h}+0.077 C_{k}
$$

Where $\mathrm{C}_{\mathrm{Ra}}, \mathrm{C}_{\mathrm{Th}}$ and $\mathrm{C}_{\mathrm{K}}$ are the activity concentrations of Ra, Th and $\mathrm{K}\left(\mathrm{Bqkg}^{-1}\right)$, respectively. The radium equivalent activities $\left(\mathrm{Ra}_{\mathrm{eq}}\right)$ have been calculated on the estimation that $370 \mathrm{Bqkg}^{-1}\left(10 \mathrm{pCi}^{-1}\right){ }^{226} \mathrm{Ra}, 259 \mathrm{~Bq} \mathrm{~kg}^{-1}(7 \mathrm{pCi} \mathrm{g}-1){ }^{232} \mathrm{Th}$ or $4810 \mathrm{~Bq} \mathrm{~kg}^{-1}$

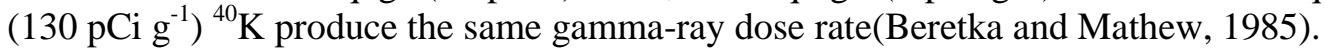

\subsection{Absorbed Dose Rate}

The absorbed dose rate in air in a room has been calculated according to RP 112 by using the specific dose rates given in EC (1999). The specific dose rates (in unitsnGyh ${ }^{1}$ perBq $\mathrm{kg}^{-1}$ ) for ${ }^{226} \mathrm{Ra},{ }^{232} \mathrm{Th}$ and ${ }^{40} \mathrm{~K}$ are given for different materials. Dose rate indoors are calculated according to the EC (1999) for materials under investigation, when used as tile on all walls by:

$$
\mathrm{D}=0.12 * \mathrm{C}_{\mathrm{Ra}}+0.14 * \mathrm{C}_{\mathrm{Th}}+0.0096 * \mathrm{C}_{\mathrm{K}}
$$


Where $\mathrm{C}_{\mathrm{Ra}}, \mathrm{C}_{\mathrm{Th}}$ and $\mathrm{C}_{\mathrm{K}}$ are the concentrations (in $\mathrm{Bq} \mathrm{kg}^{-1}$ ) of radium, thorium and potassium, respectively.

\subsection{Internal and External Hazard}

Radon and its short-lived products are also hazardous to the respiratory organs. The internal exposure to radon and its progeny products are quantified by the internal hazard index $\left(H_{i n}\right)$, which is determined by [8]

$$
H_{\text {in }}=\frac{C_{R a}}{185}+\frac{C_{T h}}{259}+\frac{C_{K}}{4810} \leq 1
$$

Where $\mathrm{C}_{\mathrm{Ra}}, \mathrm{C}_{\mathrm{Th}}$ and $\mathrm{C}_{\mathrm{K}}$ are the activity concentrations of ${ }^{226} \mathrm{Ra},{ }^{232} \mathrm{Th}$ and ${ }^{40} \mathrm{~K}\left(\mathrm{Bqkg}^{-1}\right)$, respectively.

To limit the external gamma radiation dose from ceramic materials to $1 \mathrm{mSvy}^{-1}$, the external hazard index $\left(\mathrm{H}_{\mathrm{ex}}\right)$ is determined by [8]

$$
H_{e x}=\frac{C_{R a}}{370}+\frac{C_{T h}}{259}+\frac{C_{K}}{4810} \leq 1
$$

Where $\mathrm{C}_{\mathrm{Ra}}, \mathrm{C}_{\mathrm{Th}}$ and $\mathrm{C}_{\mathrm{K}}$ are the activity concentrations of ${ }^{226} \mathrm{Ra},{ }^{232} \mathrm{Th}$ and ${ }^{40} \mathrm{~K}\left(\mathrm{~Bq} \cdot \mathrm{kg}^{-1}\right)$, respectively.

\subsection{Gamma Index (I $\gamma)$}

A number of indices dealing with the assessment of the excess gamma radiation arising from roofing tile materials $[4,8,9,10]$. The gamma-index $(\mathrm{I} \gamma)$ was calculated as proposed by the European Commission [4]:

$I \gamma=0.0067 * C_{R a}+0.01 * C_{T h}+0.00067 * C_{\mathrm{K}}$

Where $\mathrm{C}_{\mathrm{Ra}}, \mathrm{C}_{\mathrm{Th}}$ and $\mathrm{C}_{\mathrm{K}}$ are the activity concentrations of ${ }^{226} \mathrm{Ra},{ }^{232} \mathrm{Th}$ and ${ }^{40} \mathrm{~K}\left(\mathrm{~Bq} \cdot \mathrm{kg}^{-1}\right)$, respectively.

\subsection{Annual Effective Dose}

Finally, the annual effective dose rate (AED) in $\left(\mathrm{mSvy}^{-1}\right)$ due to gamma radiation from roofing materials resulting from the concentrations of radionuclides in the environment due to terrestrial gamma radiation from ${ }^{40} \mathrm{~K},{ }^{238} \mathrm{U}$ and ${ }^{232} \mathrm{Th}$, can determined by the average indoor conversion coefficient from absorbed dose rate(D) in the air and the average annual effective dose equivalent (AED). The value of the conversion factor is 0.8 $\mathrm{SvGy}^{-1}$ for gamma ray exposure in environment and the occupancy factor outdoor to be about 0.2. The AED can be calculated as follow [11]:

$$
A E D\left(\frac{\mu s v}{y}\right)=D\left(\frac{n G y}{y}\right) \times 8760\left(\frac{h}{y}\right) \times 0.2 \times 0.8\left(\frac{s v}{G y}\right) \times 10^{-3}
$$

\section{Results and Discussion:}

\subsection{Chemical Composition}

Chmical analyses for some samples underinvestigation have been done by XRF technic in the (Central laboratory Sothvalley University)Qena- Egypt. We chose sixteen samples from ceramic tile materials for that analyses for the majorelement oxides $\mathrm{SiO}_{2}, \mathrm{Al}_{2} \mathrm{O}_{3}$, $\mathrm{CaO}, \mathrm{Na}_{2} \mathrm{O}, \mathrm{TiO}_{2}, \mathrm{Fe} 2 \mathrm{O}_{3}, \mathrm{~K}_{2} \mathrm{O} \mathrm{MnO}, \mathrm{MgO}, \mathrm{ZrO}_{2}, \mathrm{ZnO}$ and $\mathrm{WO}_{3}$. The results have been listed in Table 1. 
Table 1. Chemical Composition (vol \%) of the Studied Ceramic Tile Samples

\begin{tabular}{|l|l|l|l|l|l|l|l|l|l|l|l|l|}
\hline sample & Al2O3 & SiO2 & K2O & CaO & TiO2 & MnO & Fe2O3 & ZnO & ZrO2 & Na2O & MgO & WO3 \\
\hline AIR & 16.06 & 64.24 & 1.6 & 1.5 & 1.6 & 0.41 & 12.23 & 0.26 & 0.3 & 0 & 0 & 0 \\
\hline ArH & 18.57 & 61.71 & 2.96 & 1.62 & 2.1 & 0.3 & 12.45 & 0 & 0.31 & 0 & 0 & 0 \\
\hline ArR & 17.45 & 59.7 & 2.63 & 1.82 & 1.9 & 0.42 & 15.05 & 0.41 & 0.27 & 0 & 0 & 0 \\
\hline FR & 19.61 & 58.3 & 2.52 & 1.86 & 2.19 & 0.49 & 15.04 & 0 & 0 & 0 & 0 & 0 \\
\hline FrH & 16.94 & 61.42 & 2.41 & 7.84 & 1.78 & 0 & 8.79 & 0.32 & 0.5 & 0 & 0 & 0 \\
\hline FrR & 16.05 & 57.99 & 2.9 & 10.2 & 1.78 & 0.28 & 9.44 & 0.63 & 0.75 & 0 & 0 & 0 \\
\hline GH & 17.12 & 64.98 & 3.21 & 2.14 & 1.98 & 0.28 & 9.68 & 0.32 & 0.31 & 0 & 0 & 0 \\
\hline GIH & 16.83 & 61.51 & 2.62 & 1.95 & 1.85 & 0.42 & 14.56 & 0 & 0.26 & 0 & 0 & 0 \\
\hline KR & 18.66 & 64.5 & 2 & 1.7 & 1.72 & 0 & 7.77 & 0.26 & 0.31 & 2.4 & 0.69 & 0 \\
\hline LH & 15.47 & 55.5 & 2.57 & 11.07 & 1.99 & 0.44 & 12.64 & 0.32 & 0 & 0 & 0 & 0 \\
\hline LR & 16.37 & 63.87 & 3.59 & 1.9 & 1.87 & 0.33 & 12.07 & 0 & 0 & 0 & 0 & 0 \\
\hline PG & 18.72 & 68.85 & 1.31 & 0.96 & 4.68 & 0 & 1.8 & 0 & 0 & 2.81 & 0 & 0.89 \\
\hline PK & 19.45 & 71.64 & 1.4 & 1.05 & 1.4 & 0 & 2.3 & 0 & 0.2 & 2.55 & 0 & 0 \\
\hline PPr & 19.46 & 68.92 & 1.94 & 1.21 & 2.07 & 0 & 4.45 & 0 & 0 & 1.95 & 0 & 0 \\
\hline PrR & 16.75 & 63.1 & 3.85 & 1.82 & 1.9 & 0.29 & 11.03 & 0 & 0.43 & 0 & 0.84 & 0 \\
\hline RoR & 19.11 & 64.21 & 1.29 & 2.49 & 1.71 & 0 & 7.86 & 0.31 & 0.49 & 1.57 & 0.96 & 0 \\
\hline Average & 17.66 & 63.15 & 2.43 & 3.20 & 2.03 & 0.23 & 9.82 & 0.18 & 0.26 & 0.71 & 0.16 & 0.06 \\
\hline min & 15.47 & 55.50 & 1.29 & 0.96 & 1.40 & 0.00 & 1.80 & 0.00 & 0.00 & 0.00 & 0.00 & 0.00 \\
\hline max & 19.61 & 71.64 & 3.85 & 11.07 & 4.68 & 0.49 & 15.05 & 0.63 & 0.75 & 2.81 & 0.96 & 0.89 \\
\hline
\end{tabular}

From chmeical analysis values ,that listed in Table 1 , we can observe that the contents values of oxides $\mathrm{SiO} 2, \mathrm{Al} 2 \mathrm{O} 3, \mathrm{CaO}, \mathrm{Na} 2 \mathrm{O}, \mathrm{TiO} 2, \mathrm{Fe} 2 \mathrm{O} 3, \mathrm{~K} 2 \mathrm{O} \mathrm{MnO}, \mathrm{MgO}, \mathrm{ZrO} 2, \mathrm{ZnO}$ and WO3fall within the ranges of the standard values for contents used in the ceramic industry [5]. We can found that:

1) Their $\mathrm{SiO} 2$ content ranges from 55.50 to $71.64 \%$ with an average of $63.15 \%$.

2) $\mathrm{Al} 2 \mathrm{O} 3$ content ranges from 15.47 to $19.61 \%$ withan average of $17.66 \%$

3) $\mathrm{K} 2 \mathrm{O}$ content ranges from 1.29 to $3.85 \%$ with an average of $2.43 \%$.

4) $\mathrm{CaO}$ content ranges from 0.96 to $11.07 \%$ with an average of $3.20 \%$.

5) $\mathrm{TiO} 2$ content ranges from 1.40 to $4.68 \%$ with an average of $2.03 \%$.

6) $\mathrm{Fe} 2 \mathrm{O} 3$ content ranges from 1.80 to $15.05 \%$ with an average of $1.80 \%$.

7) The rest oxides $\mathrm{Na} 2 \mathrm{O}, \mathrm{TiO} 2, \mathrm{~K} 2 \mathrm{O} \mathrm{MnO}, \mathrm{MgO}, \mathrm{ZrO} 2, \mathrm{ZnO}$ and $\mathrm{WO} 3$ there contents are less than $1 \%$.

\subsection{Activity Concentrations and Radiological Hazards}

This study is a continuation of our ongoing scientific cooperation between physics department - faculty of science, Al-Azhar university, Assiut branch, Egypt and physics department -faculty of science, Assiut university, Egypt, related to the measurement of specific activity of ${ }^{226} \mathrm{Ra},{ }^{232} \mathrm{Th}$ and ${ }^{40} \mathrm{~K}$ in environmental samples from Upper Egypt using a gamma-ray spectrometric technique and estimation of the gamma dose rate from these radionuclides. The obtained average activity concentrations of ${ }^{226} \mathrm{Ra},{ }^{232} \mathrm{Th}$ and ${ }^{40} \mathrm{~K}$ for each of measured sample together with their corresponding total uncertainties are summarized in Table 2. Where Figure 1, shows a comparison between the activity concentrations in $\mathrm{Bqkg}^{-1}$ for the all ceramic tile samples under investigation. 


\section{Table 2. Average Radioactivity Concentration in all the Ceramic Tile} Materials

\begin{tabular}{|c|c|c|c|c|}
\hline \multirow{2}{*}{$\begin{array}{c}\text { Sample } \\
\text { name }\end{array}$} & \multirow{2}{*}{$\begin{array}{c}\text { Number of } \\
\text { samples }\end{array}$} & \multicolumn{3}{|c|}{ Average activity in $\left(\mathrm{BqKg}^{-1}\right)$} \\
\hline & & ${ }^{226} \mathrm{Ra}$ & $232 \mathrm{Th}$ & $40 K$ \\
\hline $\mathrm{RoH}$ & 5 & $43.6 \pm 6.58$ & $7.25 \pm 6.9$ & $395 \pm 34.7$ \\
\hline $\mathrm{PrH}$ & 5 & $29.28 \pm 5.5$ & $36.2 \pm 5.4$ & $417.5 \pm 43.8$ \\
\hline$L H$ & 4 & $30.7 \pm 5.9$ & $37.5 \pm 6.2$ & $429.7 \pm 36.0$ \\
\hline$G l H$ & 4 & $29.4 \pm 4.9$ & $37.2 \pm 6.4$ & $370.2 \pm 33.1$ \\
\hline$G H$ & 5 & $42.71 \pm 6.5$ & $44.2 \pm 6.6$ & $471.0 \pm 50.7$ \\
\hline $\mathrm{FrH}$ & 4 & $35.46 \pm 6$ & $33.6 \pm 6.9$ & $391.4 \pm 69.8$ \\
\hline$K H$ & 2 & $43.79 \pm 7.5$ & $50.1 \pm 7.2$ & $468.5 \pm 38.7$ \\
\hline $\mathrm{ArH}$ & 4 & $44.94 \pm 5.6$ & $53 . \pm 6.6$ & $573.5 \pm 55.7$ \\
\hline$A l H$ & 4 & $36.45 \pm 5.1$ & $37.4 \pm 6.2$ & $426.6 \pm 35.9$ \\
\hline Min. & Ceramic & $29.28 \pm 5.5$ & $33.6 \pm 6.9$ & $391.4 \pm 69.8$ \\
\hline $\operatorname{Max}$. & wall & $44.94 \pm 5.6$ & $53.9 \pm 6.6$ & $573.5 \pm 55.7$ \\
\hline Mean & tiles & $37.37 \pm 2.0$ & $36.2 \pm 2.03$ & $215.7 \pm 15.2$ \\
\hline$R o R$ & 4 & $36.5 \pm 6.31$ & $38.2 \pm 6.2$ & $355 \pm 31.6$ \\
\hline $\operatorname{PrR}$ & 5 & $38.1 \pm 7.1$ & $50.0 \pm 7.5$ & $551 \pm 58.9$ \\
\hline$L R$ & 4 & $35.12 \pm 6.2$ & $44.8 \pm 6.9$ & $619.5 \pm 34.3$ \\
\hline$G l R$ & 1 & $34.3 \pm 5.8$ & $39.7 \pm 7.2$ & $444.9 \pm 39.5$ \\
\hline$G R$ & 5 & $47.18 \pm 7.4$ & $50.0 \pm 7.5$ & $595.9 \pm 63.7$ \\
\hline FrR & 5 & $35.66 \pm 5.7$ & $42.8 \pm 6.8$ & $389.9 \pm 60.5$ \\
\hline$K R$ & 5 & $40.31 \pm 7.1$ & $37.9 \pm 6.4$ & $338.7 \pm 30.7$ \\
\hline$A r R$ & 4 & $47.08 \pm 7.6$ & $55.9 \pm 10.3$ & $417.4 \pm 37.6$ \\
\hline$A l R$ & 5 & $38.53 \pm 5.9$ & $38.0 \pm 6.5$ & $457.5 \pm 38.8$ \\
\hline FrR & 5 & $25.87 \pm 5.4$ & $33.8 \pm 5.6$ & $271.3 \pm 42.2$ \\
\hline Min. & Ceramic & $25.8 \pm 5.4$ & $33.8 \pm 5.6$ & $271.3 \pm 42.2$ \\
\hline Max. & roofing & $47.1 \pm 7.3$ & $55.9 \pm 10.29$ & $619.5 \pm 34.3$ \\
\hline Mean & tiles & $37.8 \pm 1.9$ & $43.1 \pm 2.2$ & $444.1 \pm 14.4$ \\
\hline$P G$ & 4 & $35 \pm 4.7$ & $30.79 \pm 3.5$ & $163.4 \pm 10.8$ \\
\hline$P K$ & 3 & $120.4 \pm 16.4$ & $63.14 \pm 8.8$ & $180.6 \pm 16.4$ \\
\hline$P P r$ & 4 & $45.7 \pm 6.9$ & $53.38 \pm 8.4$ & $499.1 \pm 70.5$ \\
\hline Min. & Advanced & $35 \pm 4.7$ & $30.79 \pm 3.5$ & $163.4 \pm 10.8$ \\
\hline Max. & ceramic & $120.4 \pm 16.4$ & $63.14 \pm 8.8$ & $499.1 \pm 70.5$ \\
\hline Mean & (porcelain) & $49.1 \pm 4.25$ & $67.0 \pm 6.2$ & $281 \pm 7.2$ \\
\hline Min. & All & $120.4 \pm 16.5$ & $63.1 \pm 8.9$ & $163.4 \pm 10.8$ \\
\hline Max. & ceramic & $24.9 \pm 4.7$ & $29.9 \pm 4.7$ & $619.4 \pm 34.3$ \\
\hline Mean & samples & $47.4 \pm 3.3$ & $42.84 \pm 2.8$ & $313.6 \pm 34.3$ \\
\hline
\end{tabular}

From the obtained results, it can be seen that, the values of specific activity concentrations in the studied roofing tile samples varied from $24.9 \pm 4.7$ to $120.4 \pm 16.5$, $29.9 \pm 4.7$ to $63.1 \pm 8.8$ and from $163.4 \pm 10.8$ to $619.4 \pm 34.3 \mathrm{Bqkg}^{-1}$ for ${ }^{226} \mathrm{Ra}^{232} \mathrm{Th}$ and ${ }^{40} \mathrm{~K}$ respectively. The lowest $\left(24.9 \mathrm{~Bq} \mathrm{~kg}^{-1}\right)$ activity concentration of ${ }^{226} \mathrm{Ra}$ is found ceramic wall tiles $(\mathrm{PrH})$, while the largest value $\left(120.4 \mathrm{~Bq} \mathrm{~kg}^{-1}\right)$ in advanced ceramic $(\mathrm{PK})$. In the case of ${ }^{232} \mathrm{Th}$ activity the lowest value is $29.9 \mathrm{~Bq} \mathrm{~kg}^{-1}$, found in ceramic wall tiles $(\mathrm{FH})$, and the highest is $63.2 \mathrm{~Bq} \mathrm{~kg}{ }^{-1}$, again found in advanced ceramic(PK).Figure 1; represent the relative concentration of ${ }^{226} \mathrm{Ra},{ }^{232} \mathrm{Th}$ and ${ }^{40} \mathrm{~K}$ to the total activity in the samples. From that figure, we found that, the specific activity concentration due to ${ }^{40} \mathrm{~K}$ is the largest contributor to the total activity for all the samples. 


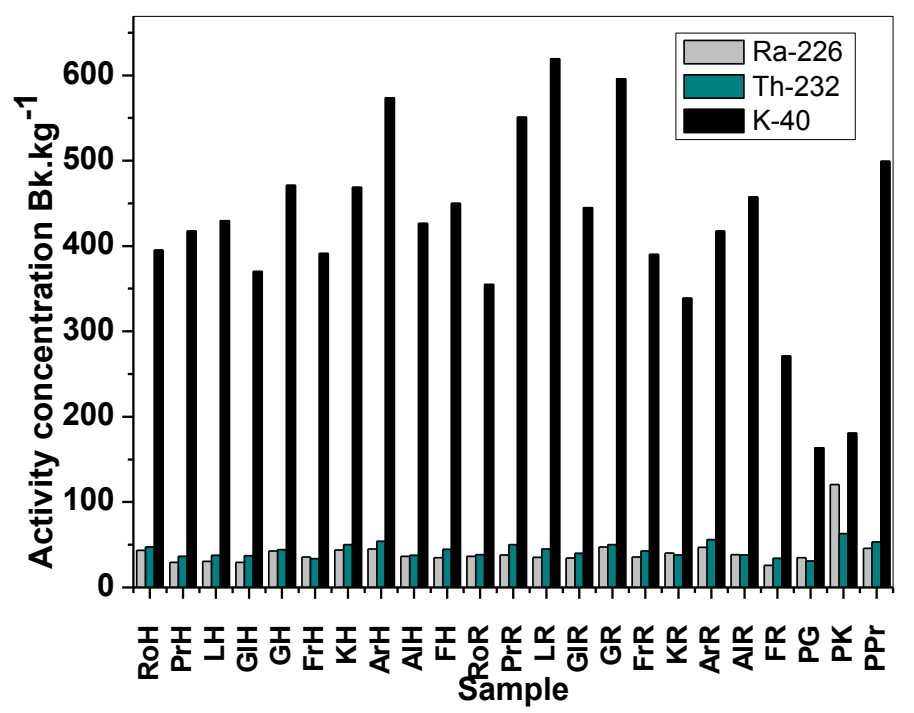

Figure 1. The Concentration of ${ }^{226} \mathrm{Ra},{ }^{232} \mathrm{Th}$ and ${ }^{40} \mathrm{~K}$ in all Ceramic Samples

To assess the radiological hazard of roofing tile samples, which used as building materials in Egypt, the radium equivalent activities $\left(\mathrm{Ra}_{\mathrm{eq}}\right)$, the indoor absorbed dose rate, internal and external hazard, Gamma radiation hazard index and annual effective dose and annual effective dose rate were calculated and listed in Table 3.

From Table 2, we can note that, the $\mathrm{Ra}_{\mathrm{eq}}$ values for the roofing tile samples varied from 87 to $222 \mathrm{Bqkg}^{-1}$, these values are less than the recommended limit value of $370 \mathrm{Bqkg}$ ${ }^{1}[11]$ and as such does not pose any radiological hazard.

Table 3. The Radiation Hazard Indices of the Samples

\begin{tabular}{|c|c|c|c|c|c|c|c|}
\hline $\begin{array}{c}\text { Sample } \\
\text { name }\end{array}$ & $\begin{array}{c}\text { Number } \\
\text { of samples }\end{array}$ & $\begin{array}{c}R a e q \\
\left(B q K g^{-1}\right)\end{array}$ & $\begin{array}{c}\text { Absorbed } \\
\text { Dose }(n G y / h)\end{array}$ & Hin & Hex & $I \gamma$ & $\begin{array}{r}A E D \\
\left(m S v y^{-1}\right)\end{array}$ \\
\hline $\mathrm{RoH}$ & 5 & 150.29 & 14.90 & 0.53 & 0.41 & 1.09 & 0.07 \\
\hline $\mathrm{PrH}$ & 5 & 113.30 & 12.80 & 0.38 & 0.31 & 0.83 & 0.06 \\
\hline$L H$ & 4 & 117.48 & 13.07 & 0.40 & 0.32 & 0.87 & 0.06 \\
\hline GlH & 4 & 111.14 & 12.29 & 0.38 & 0.29 & 0.82 & 0.06 \\
\hline GH & 5 & 142.27 & 15.84 & 0.50 & 0.38 & 1.04 & 0.08 \\
\hline FrH & 4 & 119.58 & 13.68 & 0.42 & 0.32 & 0.88 & 0.07 \\
\hline $\boldsymbol{K H}$ & 2 & 115.44 & 16.74 & 0.53 & 0.31 & 0.79 & 0.08 \\
\hline $\mathrm{ArH}$ & 4 & 166.16 & 18.44 & 0.57 & 0.45 & 1.22 & 0.09 \\
\hline AlH & 4 & 122.75 & 11.07 & 0.43 & 0.33 & 0.90 & 0.05 \\
\hline$F H$ & 5 & 87.87 & 9.69 & 0.27 & 0.24 & 0.64 & 0.05 \\
\hline Min. & Ceramic & 87.87 & 9.69 & 0.27 & 0.24 & 0.64 & 0.05 \\
\hline Max. & wall & 166.16 & 18.44 & 0.57 & 0.45 & 1.22 & 0.09 \\
\hline Mean & tiles & 124.63 & 13.85 & 0.44 & 0.34 & 0.91 & 0.07 \\
\hline RoR & 4 & 118.18 & 13.09 & 0.42 & 0.32 & 0.75 & 0.06 \\
\hline $\operatorname{PrR}$ & 5 & 151.12 & 16.63 & 0.51 & 0.41 & 0.97 & 0.08 \\
\hline$L R$ & 4 & 146.92 & 15.24 & 0.49 & 0.39 & 1.09 & 0.08 \\
\hline GlR & 1 & 125.42 & 13.95 & 0.43 & 0.34 & 0.42 & 0.07 \\
\hline$G R$ & 5 & 164.65 & 17.89 & 0.57 & 0.44 & 1.22 & 0.09 \\
\hline
\end{tabular}




\begin{tabular}{|cccccccc|}
\hline FrR & 5 & 133.86 & 12.98 & 0.46 & 0.36 & 0.99 & 0.06 \\
KR & 5 & 94.61 & 14.74 & 0.43 & 0.26 & 0.71 & 0.07 \\
ArR & 4 & 95.62 & 17.14 & 0.56 & 0.43 & 1.16 & 0.08 \\
AlR & 5 & 128.20 & 14.35 & 0.49 & 0.38 & 1.04 & 0.07 \\
FR & 5 & 99.45 & 10.96 & 0.35 & 0.26 & 0.72 & 0.05 \\
\hline Min. & Ceramic & $\mathbf{9 4 . 6 1}$ & $\mathbf{1 0 . 9 6}$ & $\mathbf{0 . 3 5}$ & $\mathbf{0 . 2 6}$ & $\mathbf{0 . 7 1}$ & $\mathbf{0 . 0 5}$ \\
Max. & roofing & $\mathbf{1 6 4 . 6 5}$ & $\mathbf{1 7 . 1 4}$ & $\mathbf{0 . 5 7}$ & $\mathbf{0 . 4 4}$ & $\mathbf{1 . 2 2}$ & $\mathbf{0 . 0 9}$ \\
Mean & tiles & $\mathbf{1 2 5 . 8 0}$ & $\mathbf{1 4 . 7 0}$ & $\mathbf{0 . 4 7}$ & $\mathbf{0 . 3 6}$ & $\mathbf{0 . 9 1}$ & $\mathbf{0 . 0 7}$ \\
\hline $\boldsymbol{P G}$ & 4 & 92.51 & 10.19 & 0.35 & 0.26 & 0.66 & 0.05 \\
$\boldsymbol{P K}$ & 3 & 221.31 & 19.53 & 0.92 & 0.59 & 1.54 & 0.10 \\
$\boldsymbol{P P r}$ & 4 & 160.51 & 17.75 & 0.55 & 0.43 & 1.17 & 0.09 \\
\hline Min. & Advanced & $\mathbf{9 2 . 5 1}$ & $\mathbf{1 0 . 1 9}$ & $\mathbf{0 . 3 5}$ & $\mathbf{0 . 2 6}$ & $\mathbf{0 . 6 6}$ & $\mathbf{0 . 5 0}$ \\
Max. & ceramic & $\mathbf{2 2 1 . 3 1}$ & $\mathbf{1 9 . 5 3}$ & $\mathbf{0 . 9 2}$ & $\mathbf{0 . 5 9}$ & $\mathbf{1 . 5 4}$ & $\mathbf{0 . 9 6}$ \\
Mean & (porcelain) & $\mathbf{1 5 8 . 1 1}$ & $\mathbf{1 5 . 8 2}$ & $\mathbf{0 . 6 1}$ & $\mathbf{0 . 4 3}$ & $\mathbf{1 . 1 2}$ & $\mathbf{0 . 0 8}$ \\
\hline Min. & All & $\mathbf{8 7 . 8 7}$ & $\mathbf{9 . 6 9}$ & $\mathbf{0 . 2 7}$ & $\mathbf{0 . 2 4}$ & $\mathbf{0 . 6 4}$ & $\mathbf{0 . 0 5}$ \\
Max. & ceramic & $\mathbf{2 2 1 . 3 1}$ & $\mathbf{1 9 . 5 3}$ & $\mathbf{0 . 9 2}$ & $\mathbf{0 . 4 5}$ & $\mathbf{1 . 5 4}$ & $\mathbf{0 . 1 0}$ \\
Mean & samples & $\mathbf{1 3 1 . 5 1}$ & $\mathbf{1 4 . 4 9}$ & $\mathbf{0 . 4 9}$ & $\mathbf{0 . 3 6}$ & $\mathbf{0 . 9 4}$ & $\mathbf{0 . 0 7}$ \\
\hline
\end{tabular}

For the safe use of the material under investigation in the construction of dwellings, $\mathrm{H}_{\text {in }}$ and $\mathrm{H}_{\mathrm{ex}}$ must be less than unity [2]. The calculated values of $\mathrm{H}_{\mathrm{in}}$ and $\mathrm{H}_{\mathrm{ex}}$ for the studied samples range from $0.27-0.92$ and $0.24-0.45$ respectively as it appear in Table 3, all these values are less than unity. The average values of absorbed dose rate (D) for all studied ceramic materials in Egypt ranging $9.69-19.53 \mathrm{nGyh}^{-1}$ are lower than average (populated-weighted) indoor absorbed gamma dose rate of $84 \mathrm{nGyh}^{-1}[11]$.

The obtained values for the annual effective dose (DE) listed in column 4 of Table 2 are in between $\left(0.05-0.10 \mathrm{mSv}^{-1}\right)$; these values were lower than the value of $1.5 \mathrm{mSv} \mathrm{y}^{-1}$ set in the NEA-OECD (1979)[34] report. According to the UNSCEAR, 2000 the annual effective dose of all samples does not exceed the average worldwide exposure of $2.4 \mathrm{mSv}$ $\mathrm{y}^{-1}$ due to natural sources. The calculated of annual effective dose rate values in all samples received by the people in housing are lower than the world allowed dose of 1 $\mathrm{mSvy}^{-1}$. This indicated that the roofing tile samples used in Egypt can be used in building construction without exceeding the proposed radioactivity criterion level. [12]. The calculated values of $\mathrm{I} \gamma$ are given in Table 3. It is clear that the majority roofing tile samples are lower than unity.

Obtained data from present study showed that the maximum levels of contaminants are within the limits of activity the concentrations of ${ }^{238} \mathrm{U},{ }^{232} \mathrm{Th}$ and ${ }^{40} \mathrm{~K}$ in $\mathrm{Bq} \mathrm{Kg}^{-1}$ in ceramic materials available in other countries of the world, which are listed in Table 3.

Table 3. Comparison between Average Activity Concentrations of Investigated Samples with those in other Countries

\begin{tabular}{|ccccc|}
\hline Countries & ${ }^{226} \mathrm{Ra}$ & ${ }^{232} \mathrm{Th}$ & ${ }^{40} \mathrm{~K}$ & References \\
\hline Norway & 104 & 62 & 1058 & {$[13]$} \\
UK & 52 & 44 & 703 & {$[9]$} \\
Germany & 59 & 67 & 673 & {$[9]$} \\
Sweden & 96 & 127 & 962 & {$[9]$} \\
Malaysia & 233 & 229 & 685 & {$[14]$} \\
\hline
\end{tabular}




\begin{tabular}{|c|c|c|c|c|}
\hline Austria & 38 & 45 & 635 & [15] \\
\hline Netherlands & 39 & 41 & 560 & {$[16]$} \\
\hline Australia & 41 & 89 & 681 & {$[8]$} \\
\hline Brazil & 52 & 65 & 747 & [17] \\
\hline Hon Kong & 78 & 100 & 627 & [18] \\
\hline Zambia & 32 & 81 & 412 & [19] \\
\hline Kuwait & 7 & 7 & 332 & [20] \\
\hline Kenya & 17 & 52 & 379 & {$[21]$} \\
\hline Bangladesh & 29 & 53 & 292 & [22] \\
\hline Egypt & 25 & 24 & 258 & {$[23]$} \\
\hline India & 48 & 52 & 381 & [24] \\
\hline Algeria & 65 & 51 & 675 & [25] \\
\hline Srilanka & 35 & 72 & 585 & {$[26]$} \\
\hline Poland & 50 & 50 & 963 & [27] \\
\hline Greece & 35 & 45 & 710 & {$[28]$} \\
\hline Italy & 58 & 51 & 473 & [29] \\
\hline Cameroon & 50 & 91 & 172 & [30] \\
\hline Pakistan & 46 & 62 & 693 & {$[31]$} \\
\hline Iran & 33 & 30 & 700 & [32] \\
\hline China & 38 & 47 & 697 & [33] \\
\hline Turkey & 34 & 33 & 429 & [12] \\
\hline Egypt(2013) & 52 & 81 & 268 & [2] \\
\hline Egypt (2015) & 47 & 43 & 314 & Present study \\
\hline
\end{tabular}

As shown in Table 3, the radioactivity in selected materials differ from one country to another. It is important to point out that these values are not the values representative of the countries listed, but the areas where the collected samples [2].

\section{Conclusion}

In this study the activity levels of roofing tile materials in Egypt have been measured using HPGe $\gamma$-ray spectrometer. The results show the activity concentrations of ${ }^{226} \mathrm{Ra}$, ${ }^{232} \mathrm{Th}$ and ${ }^{40} \mathrm{~K}$ in all samples are in the range of acceptable value. The average Raeq values of the studied samples are below the world accepted values $\left(370 \mathrm{Bqkg}^{-1}\right)$. The calculated total annual effective doses of all roofing tile materials are lower than $1 \mathrm{mSvy}^{-1}$. Also the internal hazard index and external hazard index of roofing tile materials are less than unity. The quantitative results indicate that, most of roofing tile materials does not pose 
any significant source of radiation hazard, however, the use of these roofing tile materials for the construction of dwellings is considered to be safe for inhabitants.

\section{References}

[1] R. Casasola, J. M. Rincón and M. Romero, "Glass-ceramic glazes for ceramic tiles: a review”, Mater, Sci., vol. 47, (2012), pp. 553-582.

[2] M. A. M. Uosif, "Quantitative measurement of natural radioactivity in some roofing tile materials used in Upper Egypt", Radi. Prot. Dosi., vol. 156, no. 2, (2013), pp. 231-238.

[3] S. Righi, A. Albertazzi, R. Guerra, M. Jeyapandian, S. Verità", Natural radioactivity in Italian ceramic tiles, (2010).

[4] EC (European Commission), Radiation Protection 112. Radiological Protection Principles Concerning the Natural Radioactivity of Building Materials. Directorate-General Environment, Nuclear Safety and Civil Protection, (1999).

[5] M. A. M. Uosif and L. M. Abdel-Salam, "An assessment of the external radiological impact in granites and pegmatite in central eastern desert in Egypt with elevated natural radioactivity", Radi. Prot. Dosi., vol. 147, no. 3, (2011), pp. 467-473.

[6] S. Issa, Mohamed Uosif and Reda Elsaman, "Gamma radioactivity measurements in Nile River sediment samples”, Turkish J Eng. Env. Sci., vol. 37, (2013), pp. 109-122.

[7] M. A. M. Uosif, "Gamma-ray spectroscopic analysis of selected samples from Nile river sediments in Upper Egypt", Rad. Prot. Dosi., vol. 123, no. 2, (2007), pp. 215-220.

[8] J. Beretka and P. J. Mathew, "Natural radioactivity of Australian building materials", industrial wastes and by-products. Health Phys., vol. 48, (1985), pp. 87-95.

[9] OECD, "Exposure to Radiation from the Natural Radioactivity in Building Materials", Report by a Group of Experts of the OECD Nuclear Energy Agency, Organization for Economic Co-operation and Development, (1979).

[10] V. R. Krieger, "Radioactivity of construction materials", BetonwerkFertigteilTech., vol. 47, (1981), pp. 468-473.

[11] UNSCEAR, “United Nations Scientific Committee on the Effect of Atomic Radiation”, Sources, Effects and Ionizing Radiation. United Nation, New York, (2000).

[12] N. Damla, U. Cevik, A. I. Kobya, B. Ataksor and U. Isık, "Assessment of environmental radioactivity for Batman", Turkey. Environ. Monit. Assess., vol. 160, no. 1e4, (2010), pp. 401-412.

[13] E. Stranden, "Some aspects on radioactivity of building materials", Phys. Norv., vol. 8, (1976), pp. 167173.

[14] C. S. Chong and G. U. Ahmad, "Gamma activity of some building materials in West Malaysia", Health Phys., vol. 43, (1982), pp. 272-273.

[15] H. Sorantin and F. Steger, Natural radioactivity of building materials in Austria.Radiat. Prot. Dosim., vol. 7, (1984), pp. 59-61.

[16] J. G. Ackers, J. F. den Boer, P. de Jong and N. Wolschrijn, "Radioactivity and radon exhalation rates of building materials in The Netherlands", Sci. Total Environ., vol. 45, (1985), pp. 151-156.

[17] A. Malanca, V. Pessina and G. Dallara, "Radionuclide content of building materials and gamma-ray dose rates in dwellings of Rio-Grande Do-Norte Brazil”, Radiat. Prot. Dosim., vol. 48, (1993), pp. 199203.

[18] C. Y. Ng, J. K. C. Leung and M. Y. W. Tso, "Modelling exposure to naturally occurring radionuclides in building materials", Radiat. Prot. Dosim., vol. 59, no. 1, (1985), pp. 43-48.

[19] P. Hayumbu, M. B. Zaman, N. C. H. Lubaba, S. S. Munsanje and D. Nuleya, "Natural radioactivity in Zambian building materials collected from Lusaka", Radioanal.Nucl. Ch., vol. 199, (1995), pp. 229-238.

[20] K. Bau-Rabee and H. Bem, "Natural radioactivity in building materials utilized in the state of Kuwait", Radioanal. Nucl. Chem. Lett., vol. 213, no. 2, (1996), pp. 143-149.

[21] A. O. Mustapha, D. G. S. Narayana, J. P. Patel and D. Otwoma, "Natural radioactivity in spme building materials in Kenya and their contributions to the indoor", (1997).

[22] M. I. Chowdury, M. N. Alam and A. K. S. Ahmed, "Concentration of radionuclides in building and ceramic materials of Bangladesh and evaluation of radiation hazard", Radioanal. Nucl. Ch., vol. 231, (1998), pp. 117-123.

[23] M. Sharaf, M. Mansy, A. El Sayed and E. Abbas, "Natural radioactivity and radon exhalation rates in building materials used in Egypt", Radiat. Meas., vol. 31, (1999), pp. 491-495.

[24] V. Kumar, T. V. Ramachandran and R. Prasad, "Natural radioactivity of Indian building materials and by-products", Appl. Radiat. Isotopes, vol. 51, (1999), pp. 93-96.

[25] D. Amrani and M. Tahtat, "Natural radioactivity in Algerian building materials", Appl. Radiat. Isotopes, vol. 54 , no. 4, pp. 687-689.

[26] R. Hewamanna, C. S. Sumithrarachchi, P. Mahawatte, H. L. Nanayakkara and H. C. Ratnayake, "Natural radioactivity and gamma dose from Sri Lankan clay bricks used in building construction", Appl. Radiat. Isotopes, vol. 54, (2001), pp. 365-369. 
[27] M. Zalewski, M. Tomczak and J. Kapata, "Radioactivity of building materials available in Northeastern Poland", Pol. J. Environ. Stud., vol. 10, no. 3, (2001), pp. 183-188.

[28] S. Stoulos, M. Manolopoulou and C. Papastefanou, "Assessment of natural radiation exposure and radon exhalation from building materials in Greece", J. Environ. Radioactiv, vol. 69, no. 3, (2003), pp. 225240.

[29] S. Righi and L. Bruzzi, "Natural radioactivity and radon exhalation in building materials used in Italian dwellings", Environ. Radioactiv, vol. 88, (2006), pp. 158-170.

[30] M. Ngachin, M. Garavaglia, C. Giovani, M. G. KwatoNjock and A. Nourreddine, "Assessment of natural radioactivity and associated radiation hazards in some Cameroonian building materials", Radiat. Meas., vol. 42, (2007), pp. 61-67.

[31] M. Tufail, N. Akthar, S. Javed and T. Hamid, "Natural radioactivity hazards of building bricks fabricated from saline soil of two districts of Pakistan", Radiological Prot., vol. 27, (2007), pp. 481-492.

[32] A. A. Fathivand, J. Amidi and A. Najafi, "The natural radioactivity in the bricks used for the construction of the dwelling in Tehran areas of Iran”, Radiat. Prot. Dosim., vol. 123, no. 3, (2007), pp. 391-393.

[33] X. Lu and X. Zhang, "Radionuclide content and associated radiation hazards of building materials and by-products in Baoji”, China. Radiat. Prot. Dosim., vol. 128, (2008), pp. 471-476.

[34] NEA-OECD, "Nuclear Energy Agency.Exposure to radiation from natural radioactivity in building materials", Report by NEA Group of Experts. OECD, (1979). 
International Journal of Advanced Science and Technology Vol.80 (2015) 